\title{
SEMAKAN KEHAKIMAN KESALAHAN JENAYAH SYARIAH DI MALAYSIA: ULASAN LITERATUR
}

\section{Judicial Review of Shariah Criminal Offences in Malaysia: A Literature Review}

\author{
Noranizan Mohd Sufian \\ Master Candidate, Department of Shariah and Law, \\ Academy of Islamic Studies, \\ University of Malaya, 50603 Kuala Lumpur. \\ anizan_sufi@yahoo.com \\ Narizan Abdul Rahman \\ Senior Lecturer, Department of Shariah and Law, \\ Academy of Islamic Studies, \\ University of Malaya, 50603 Kuala Lumpur. \\ izan@um.edu.my \\ Mazni Abdul Wahab \\ Senior Lecturer, Department of Shariah and Law, \\ Academy of Islamic Studies, \\ University of Malaya, 50603 Kuala Lumpur. \\ mazwa@um.edu.my
}

\begin{abstract}
Shariah Criminal Offences in Malaysia has been codified in all States Shariah Criminal Offences Enactment. The primary basis of authority is as enshrined under List II of the Ninth Schedule of the Federal Constitution which empowers the Shariah Court to hear any cases involving Muslims and subject matter governed under the Shariah laws. Article 121 (1A) of the Federal Constitution stipulates that Civil Court shall have no jurisdiction in respect of any matter within the jurisdiction of the Shariah Court. However, the purpose of the amendment has not been fully achieved as Civil Court still could exercise its review over matters enforced under the Shariah laws. Judicial review is an administrative process available to an aggrieved individual or
\end{abstract}


corporation challenging the validity of the decision of public authorities, including Shariah enforcement body. Notably, prior to the amendment, there were many cases of shariah related been tried and reviewed in Civil Courts including family and Shariah criminal offences. The amendment has to certain extents succeeds in reducing such review. To date, civil court continues exercising this power particularly in Shariah criminal offences on the basis of inconsistency with the Federal Constitution. This article identifies and analyse writings and works of scholarly nature which relate to civil court judicial review and its relation to Shariah laws in Malaysia, in particular the review over Shariah criminal offences in Malaysia. It employs library research in full. The study has found that not much works of scholarly nature had been done in this area, though previous works had paved way to the present study.

Keywords: judicial review, Shariah criminal offences, Federal Constitution, Shariah Court, Civil Court

\section{PENGENALAN}

Semakan Kehakiman (judicial review) bermaksud suatu proses di mana Mahkamah Tinggi menjalankan bidangkuasa pengawasan ke atas prosiding dan keputusan mahkamah yang lebih rendah, tribunal, badan-badan atau individu yang menjalankan fungsi kuasi kehakiman atau yang menjalankan tugas-tugas awam (Halsbury Law of Malaysia, 2001: 78). Ia merupakan satu jalan yang digunakan oleh pihak yang terkilan untuk mencabar kesahan suatu proses membuat keputusan oleh pihak berkuasa awam (Wan Azlan Ahmad et al., 2006: 7). Peter Cane pula menjelaskan bahawa semakan kehakiman itu adalah ketidaksahan suatu undang-undang yang digubal secara normal atau melalui proses perundangan biasa kerana ianya mempunyai konflik dengan undang-undang yang lebih tinggi seperti Perlembagaan atau triti (Peter Cane, 2004: 16). Tujuan semakan kehakiman adalah untuk memastikan setiap individu diberi layanan yang adil dan sama rata oleh pihak berkuasa dalam menjalankan kuasa membuat suatu keputusan (Khairil Azmin Mokhtar et al, 2013: 7). Isu mengenai semakan kehakiman oleh Mahkamah Sivil menjadi perhatian apabila ia dijalankan ke atas kes-kes jenayah syariah yang mana secara dasarnya difahami bahawa perkara berkaitan Hukum Syarak adalah tertakluk di bawah bidangkuasa Mahkamah Syariah.

Namun begitu, peruntukan undang-undang bagi semakan kehakiman adalah tertakluk di bawah bidangkuasa Mahkamah Sivil melalui Seksyen 25 
(2) Jadual Perenggan 1 Akta Mahkamah Kehakiman 1964 (Akta 91), Seksyen 41, Seksyen 44, Seksyen 50 hingga 55 Akta Relif Spesifik 1950 (Akta 137) dan Kaedah 1 hingga 9 Kaedah-kaedah Mahkamah 2012.

Artikel ini bertitik tolak dari kes-kes semakan kehakiman yang dibuat oleh Mahkamah Sivil, khususnya Mahkamah Tinggi terhadap penguatkuasaan kesalahan jenayah syariah yang mana pada akhirnya keputusan semakan tersebut bertentangan dengan peruntukan enakmen jenayah syariah yang sedia ada. Sekaligus ia mempersoalkan undang-undang dan mencabar Enakmen Kesalahan Jenayah Syariah negeri-negeri. Kini, semakin banyak semakan kehakiman terhadap kes-kes jenayah syariah dibuat. Antara kesalahankesalahan jenayah syariah yang terkandung dalam Enakmen Kesalahan Jenayah Syariah ialah kesalahan yang berhubungan dengan aqidah, kesalahan yang berhubungan dengan kesucian agama Islam dan institusinya, kesalahan yang berhubungan dengan kesusilaan dan kesalahan pelbagai. Peruntukan kesalahan jenayah syariah yang diperuntukkan dalam enakmen setiap negeri adalah hampir sama, namun yang membezakannya adalah nama atau jenis kesalahan, seksyen dan bentuk hukuman yang diperuntukkan.

Semakan kehakiman terhadap kes jenayah syariah berlaku apabila pihakpihak tidak berpuas hati dengan keputusan tindakan badan penguatkuasaan undang-undang kesalahan jenayah syariah atau keputusan Mahkamah Syariah. Oleh yang demikian, pihak-pihak yang dikenakan tuduhan akan mempertikaikan kes ke peringkat yang lebih tinggi atas dakwaan bahawa badan penguatkuasaan jenayah syariah telah melanggar hak asasi mereka sebagaimana yang telah diperuntukkan dalam Perlembagaan Persekutuan. Antara pelanggaran kebebasan asasi yang selalu dibangkitkan adalah seperti Perkara 5 (kebebasan diri), Perkara 8 (kesamarataan), Perkara 10 (kebebasan bercakap, berhimpun dan berpersatuan) dan Perkara 11 (kebebasan beragama).

Perlu dinyatakan, ianya bukanlah satu isu yang baru, kerana berdasarkan kepada kes-kes berkaitan Syariah dahulu yang dilaporkan, semakan kehakiman ini sememangnya telah berlaku pada ketika itu. Namun begitu, ianya kurang diberi perhatian kerana lebih banyak melibatkan kes-kes mal (sivil) dan tidak ketara dalam hal-hal jenayah syariah. Tambahan lagi, istilah semakan kehakiman khususnya dalam kes jenayah syariah masih belum menjadi satu polemik sepertimana yang berlaku pada masa kini. Terkini, beberapa kes yang dilaporkan, antaranya Muhamad Juzaili Mohd Khamis \& Ors. lwn. Kerajaan Negeri Sembilan \& Lain-lain, Sulaiman Takrib lwn. Kerajaan Negeri Terengganu, Fathul Bari Mat Jahya lwn. Majlis Agama Islam Negeri Sembilan dan Berjaya Books Sdn Bhd \& Lain-lain lwn. Jabatan Agama Islam 
Wilayah Persekutuan \& Ors., telah dibincangkan dengan meluas oleh sarjana perundangan.

Artikel ini meninjau penulisan-penulisan yang telah diterbitkan oleh sarjana-sarjana dan penulis-penulis perundangan berhubung dengan semakan kehakiman, khususnya yang menjurus kepada semakan kehakiman Mahkamah Sivil terhadap kes-kes berkaitan jenayah syariah. Sorotan literatur ini dibahagikan kepada tiga tema iaitu semakan kehakiman dalam perundangan di Malaysia, kedudukan Mahkamah Syariah di Malaysia dan kesalahan jenayah Syariah dalam kerangka perundangan di Malaysia.

\section{SEMAKAN KEHAKIMAN DI MALAYSIA}

Penulisan yang menjurus kepada semakan kehakiman Mahkamah Sivil terhadap kesalahan jenayah syariah di Malaysia tidak banyak diterbitkan. Namun, terdapat kajian dan penulisan yang membincangkan tentang konsep semakan kehakiman dalam Undang-undang Pentadbiran di Malaysia berserta kes-kes sivil yang dilaporkan. Wan Azlan Ahmad dan Nik Ahmad Kamal Nik Mahmod (2006: 1-52, 207-259) membincangkan secara menyeluruh mengenai konsep semakan kehakiman dalam Undang-undang Pentadbiran di Malaysia. Ia menyentuh mengenai Undang-undang Pentadbiran, elemen-elemen dalam semakan kehakiman, prosedur, remedi yang diperuntukkan, kes-kes yang dilaporkan dan lain-lain. Penulis menyatakan bahawa semakan kehakiman merupakan tulang belakang kepada Undang-undang Pentadbiran dan ultra vires pula adalah tulang belakang kepada semakan kehakiman. Ia merupakan alat kehakiman yang berkesan bagi pihak-pihak terkilan untuk mencabar kesahan suatu proses membuat keputusan oleh pihak berkuasa awam. Tujuannya adalah untuk memastikan sama ada suatu undang-undang itu dipatuhi atau tidak, dan bukannya bertujuan untuk menggantikan suatu keputusan yang telah dibuat. Khairil Azmin dan Siti Aliza Alias (2013: 7) menyatakan bahawa semakan kehakiman adalah satu alat kehakiman yang baik untuk badan kehakiman menjalankan prinsip semak dan imbang terhadap badan legislatif dan eksekutif. Tujuannya adalah untuk memastikan keseimbangan kuasa antara ketiga-tiga badan pentadbiran ini. Malaysia mengamalkan doktrin pengasingan kuasa iaitu badan pentadbiran seperti eksekutif, legislatif dan kehakiman mempunyai bidangkuasa tertentu yang telah ditetapkan. Maka, kuasa yang diberikan itu tidak boleh melebihi mana-mana badan pentadbiran yang lain.

Hari Chand (1998: 1-22) dalam artikelnya membincangkan mengenai had kuasa semakan kehakiman di Malaysia dengan merujuk kepada beberapa kes di Mahkamah Sivil. Antaranya ialah dalam kes Rama Chadran R. v. The Industrial Court of Malaysia \& Anor, Hakim menyatakan kuasa Mahkamah 
Tinggi dalam remedi Undang-undang Awam Malaysia adalah tidak terhad sama seperti di United Kingdom yang mana di Malaysia tiada peruntukan yang menyekat mengenainya. Dalam peruntukan Akta 91 mahupun Kaedah 2012 tidak dijelaskan secara nyata atau tersirat mengenai halangan Mahkamah Tinggi untuk memberikan apa-apa relif. Beliau menambah semakan kehakiman adalah untuk menyemak proses membuat suatu keputusan (decision making process) dan bukannya untuk mengubah suatu keputusan yang telah dibuat. Sekiranya semakan kehakiman itu dibenarkan untuk merit keputusan sesuatu kes, maka tidak ada beza antara semakan kehakiman dan rayuan. Choo Chin Thye (2002: cxx) menyatakan bahawa kuasa Mahkamah Tinggi untuk memberikan remedi kepada pihak-pihak yang terlibat adalah luas dan fleksibel.

Walaupun kuasa semakan kehakiman tidak dinyatakan secara jelas dalam Perlembagaan Persekutuan, tetapi ia boleh dilihat dalam doktrin pengasingan kuasa yang membincangkan mengenai prinsip semak dan imbang. Oleh itu, masih ada ruang untuk melakukan penambahbaikan dalam doktrin semakan kehakiman dan salah satu caranya adalah kreativiti daripada para hakim (Ahmad Masum, 2010: cxvii). Namun, Abdul Samat Musa (1997: 21) pula menyatakan bahawa kuasa semakan kehakiman boleh dilihat dalam Perkara 4 (3) dan (4), Perkara 128 (1) dan (2) dan Perkara 130 Perlembagaan Persekutuan. Beliau turut menyentuh secara ringkas mengenai semakan kehakiman Islam dalam Perlembagaan Pakistan dan Perlembagaan Iran yang mengamalkan konsep ketertinggian Syariah. Ini bermaksud, tiada mana-mana peruntukan atau undang-undang yang boleh melebihi Perlembagaan Negara yang meletakkan al-Quran dan al-Sunnah sebagai sumber undang-undang yang tertinggi.

Penulisan oleh Gan Ching Chuan (1991: 1vii), yang menyentuh mengenai semakan kehakiman sebelum dan selepas pindaan tahun 1989 dalam Akta Keselamatan Dalam Negeri 1960 menyatakan secara ringkas bahawa sebelum pindaan Akta 1960, semakan kehakiman boleh dibuat tetapi selepas pindaan Akta ini, semakan kehakiman tidak lagi dibenarkan terhadap pesalah di bawah Akta ini. Wan Azlan dan Mohsin Hingun (1995: 31-38) membincangkan tentang konsep semakan kehakiman dalam Undang-undang Pentadbiran yang mana badan berkuasa awam mempunyai kuasa untuk membuat sesuatu tindakan, akan tetapi tidak boleh melebihi had kuasanya itu. Penulis turut menyatakan bahawa semakan dan rayuan merupakan asas kepada Undangundang Pentadbiran. Manakala penulisan Shaikh Salim Shaikh Salleh (2001: 137-139) pula menyentuh kecil tentang peranan mahkamah dalam mengawal perundangan kecil daripada disalahgunakan. Mahkamah merujuk kepada prinsip ultra vires dan mana-mana pihak yang terkilan dengan suatu perundangan kecil boleh mencabar tentang kesahan perundangan kecil itu di mahkamah dan tindakan ini merujuk kepada semakan kehakiman. Abdul Samat 
Musa dan Zuliza Kusrin (2006: 349-362) membincangkan secara ringkas mengenai Undang-undang Pentadbiran yang mempunyai kaitan dengan semakan kehakiman. Penulis membezakan antara rayuan dan semakan iaitu rayuan menyentuh berkenaan persoalan kesahihan sesuatu undang-undang, fakta, merit atau gabungan antara mana-mana perkara tersebut. Manakala, semakan adalah berkaitan dengan persoalan tindakan yang dilaksanakan dalam mana-mana badan pentadbiran.

Terdapat juga penulisan mengenai semakan kehakiman Islam. Antaranya ialah tulisan David S. Power (1992: 315-338), yang menyatakan bahawa semakan kehakiman dalam Negara Islam kali pertama didokumenkan melalui kajian mengenai sistem Undang-undang bagi masyarakat beragama Islam adalah di Morocco pada abad ke 14. Namun begitu, semakan kehakiman yang dirujuk oleh penulis adalah semakan oleh mahkamah terhadap satu mahkamah yang lain mengenai persoalan undang-undang dan bukannya semakan Mahkamah Tinggi untuk mengisytiharkan sesuatu statut atau tindakan kerajaan itu adalah tidak berperlembagaan. Kajian penulis juga lebih menjelaskan tentang konsep rayuan iaitu Undang-undang Islam membenarkan untuk menukar semula keputusan kehakiman yang diputuskan oleh hakim di bawah keadaan tertentu. Sedangkan semakan kehakiman yang dimaksudkan bukanlah untuk menukar sesuatu keputusan yang telah diputuskan tetapi adalah semakan terhadap proses membuat sesuatu keputusan.

Kajian Abdulfatai Sombo dan Hunud Abia Kadouf (2014: 33-49) pula menjurus kepada semakan kehakiman zaman awal kemunculan Islam dan bidangkuasa kehakiman mengenai persoalan-persoalan politik dari perspektif perundangan Islam. Dapatan kajian menunjukkan bahawa semakan kehakiman telah wujud pada zaman awal kemunculan Islam iaitu setelah kewafatan Nabi Muhammad SAW. Penulis berpendapat bahawa kebanyakan penulisan ilmiah dalam bidang kehakiman Islam mengabaikan perbincangan tentang kuasa semakan kehakiman dalam persoalan politik di bawah perundangan Islam. Penulis turut menjelaskan Islam mempunyai dua mekanisme asas untuk menyemak tindakan pemerintah iaitu badan kehakiman bebas dan institusi Wali al-Mazālim. Ianya adalah sistem yang efektif bagi prinsip semak dan imbang terhadap kuasa autokratik yang berdaulat. Namun ianya semakin hilang dan tidak diamalkan dalam kebanyakan negara-negara Islam kontemporari.

Manakala Nayel Musa Shaker al-Omran et al. (2015: 1-11) pula membincangkan konsep sama ada semakan kehakiman dalam perundangan Islam diakui ataupun tidak. Perlembagaan utama perundangan negara Islam ketika itu adalah merujuk kepada al-Quran dan al-sunnah, maka sekiranya terdapat mana-mana peruntukan atau perintah yang bertentangan dengan sumber tersebut, ia dianggap batal serta tidak perlu dipatuhi. Terdapat banyak 
contoh kes pada zaman perundangan Islam terdahulu yang menolak perintah, undang-undang atau keputusan yang bercanggah dengan Syariah. Selain itu, turut dibincangkan tentang prinsip pengasingan kuasa dalam perundangan Islam dan Perlembagaan utama dalam Islam. Siti Rohida Asrani dan Zuliza Kusrin (2016: 84-89) dalam kajian mereka membincangkan konsep semak dan imbang menurut Islam dan aplikasinya dalam sistem kehakiman Islam di Malaysia. Penulisan turut menyatakan secara ringkas mengenai rayuan yang boleh dilakukan ke atas mahkamah yang lebih tinggi apabila mana-mana pihak tidak berpuas hati dengan keputusan yang telah dibuat dan semakan kehakiman pula berlaku apabila terdapat bantahan ketika prosiding dijalankan dan sebelum keputusan dikeluarkan. Walau bagaimanapun, semua penulisan ini tidak membincangkan semakan kehakiman dari perspektif Undang-undang Jenayah Syariah kini secara khusus.

Manakala kajian di peringkat Sarjana antaranya ialah Dina Imam Supaat (2000: 30), yang membincangkan tentang saluran selain mahkamah bagi orang awam yang terkilan untuk membuat semakan kehakiman dan mendapatkan remedi terhadap sebarang keputusan atau tindakan pentadbiran oleh pegawai kerajaan di Malaysia. Penulis memfokuskan saluran kepada Biro Pengaduan Awam, kawalan Parlimen, Jabatan Semakan, tribunal dan Institusi Ombudsmen. Namun, kajian ini juga bukan secara langsung merujuk kepada konsep semakan kehakiman oleh Mahkamah Sivil. Penulisan Suzana Muhamad Said (2001: 20) pula dilihat lebih banyak memberikan definisi mengenai semakan kehakiman. Namun begitu, remedi dalam semakan kehakiman tidak dikupas secara mendalam dan hanya ditumpukan kepada remedi mandamus dan certiorari sahaja. Penulis turut membuat perbandingan semakan kehakiman antara Malaysia dan Australia. Perbezaan yang paling jelas ialah semakan kehakiman di Australia menggunakan statut khusus iaitu Administrative Decisions (Judial Review) Act 1977, manakala di Malaysia tidak berasaskan mana-mana statut peruntukan. Selain itu, kupasan juga tidak mendalam mengenai masalah, halangan dan cabaran yang dihadapi dalam semakan kehakiman di Malaysia. Namun, penulis ada mencadangkan untuk mewujudkan Akta Semakan Kehakiman Malaysia agar dapat memberikan keseragaman dan pemakaiannya lebih teratur.

Kajian Jayanthi Naidu (2004: 44) membincangkan tentang fungsi bidangkuasa pengawasan Mahkamah dalam melakukan semakan terhadap tindakan badan pentadbiran. Penulis turut menyatakan bahawa hubungkait antara semakan kehakiman dengan Perlembagaan adalah suatu yang sukar untuk dijelaskan, tetapi bukanlah bermakna Perlembagaan menafikan kewujudan semakan kehakiman. Ini kerana, ianya boleh dilihat dalam Perkara 4 (3) dan (4), Perkara 128 dan Perkara 130. Namun begitu, untuk merujuk 
semakan kehakiman berdasarkan kepada peruntukan-peruntukan ini adalah suatu yang kurang tepat. Selain itu, turut diulas mengenai beberapa kes Mahkamah Sivil berkaitan dengan semakan terhadap Perlembagaan.

\section{KEDUDUKAN MAHKAMAH SYARIAH DI MALAYSIA}

Kajian mengenai kedudukan Mahkamah Syariah di Malaysia telah banyak dikaji dan boleh dianggap sebagai satu penyelidikan yang sangat aktif di Malaysia. Penulisan umum mengenai konsep bidangkuasa Mahkamah Syariah paling banyak dikupas. Ia menyentuh mengenai sumber perundangan Mahkamah Syariah seperti yang termaktub dalam Perlembagaan Persekutuan, penubuhan dan struktur mahkamah, bidangkuasa Sivil dan Jenayah Mahkamah Syariah dengan merujuk kepada peruntukan Enakmen Pentadbiran Negeri dan kes-kes yang dilaporkan. Antaranya ialah buku Farid Sufian Shuaib (2008) dan artikel-artikel Mahmud Saedon A. Othman (1990: 1-18), Ahmad Ibrahim (1995: 1-10), Ghazali Abdul Rahman (1997: 139-152) dan (2007: 363-371), Abd. Jalil Borhan (1998: 24-30), Mohamed Azam Mohamed Adil (2000: 103119), Ibnor Azli Ibrahim dan Yazid Ahmad (2005: 101-108) dan lain-lain. Seterusnya, terdapat juga kajian mengenai pentadbiran Undang-undang Islam yang membincangkan mengenai kedudukan Mahkamah Syariah mengikut fasa zaman sebelum penjajahan, semasa penjajahan, dan selepas merdeka. Penulis juga merujuk kepada beberapa kes yang telah direkodkan ketika itu. Antaranya ialah kajian Ahmad Ibrahim (1993: 41-57), (1995: 11-26) dan (1997: 119-134), Zaini Nasohah (2004: 61-73), dan Ramizah Wan Muhammad (2011: 242-252).

Oleh kerana Malaysia mempunyai dua sistem mahkamah dalam hal perkara undang-undang peribadi, iaitu Mahkamah Syariah dan Mahkamah Sivil, maka pastinya berlaku konflik perundangan antara kedua mahkamah ini. Isu ini juga telah banyak dibincangkan dan dikaji. Walaupun pada tahun 1988, parlimen telah membuat pindaan Perlembagaan Persekutuan dalam perkara 121 dengan memasukkan perkara (1A), namun sehingga kini isu ini masih berlaku. Narizan Abdul Rahman (1999: 63-84), dalam kajiannya membincangkan berkenaan kes-kes yang menghadapi pertindihan bidangkuasa seperti kes Ainan Mahamad lwn Syed Abu Bakar, Roberts lwn Ummi Kalthum, Nafsiah lwn. Abd Majid, Shahimin Faizul Kung lwn. Asma Haji Junus dan Ng Wan Chan lwn. Majlis Agama Islam Wilayah Persekutuan \& Anor. Bagaimanapun, penulisan lebih memfokuskan kepada jenayah syariah liwat dalam kes Sukma Darmawan Sasmitaat Madja. Penulis yang sama juga turut mengupas mengenai konflik perundangan secara umum dan khusus dalam artikelnya Bidangkuasa Mahkamah dan Konflik Perundangan (2005: 51-69). Perbahasan umum melibatkan potensi konflik masa depan dengan merujuk kepada 
beberapa akta seperti Akta Keterangan 1950 dan Akta Penjagaan Kanak-Kanak 1981 yang mempunyai beberapa percanggahan dengan peruntukan Undangundang Islam. Perbahasan khusus pula melibatkan beberapa kes di bawah isu pemelukan Islam, jenayah Islam, pentadbiran pusaka, wakaf, perbankan dan kewangan Islam.

Abdul Hamid Mohamad (2002: 143) dalam kajiannya pula membincangkan tentang konflik bidangkuasa antara Mahkamah Syariah dan Mahkamah Sivil dengan merujuk kepada beberapa kes sivil dan jenayah. Penulis menyatakan cadangan penyelesaian, untuk menyatukan Mahkamah Sivil dan Syariah. Individu yang mempunyai kelayakan dalam Undang-undang Sivil dan Undangundang Islam hendaklah dilantik menjadi hakim di mahkamah yang sama. Sekiranya terdapat kes yang melibatkan isu Undang-undang Sivil dan Jenayah Islam, maka kes tersebut hendaklah dibicarakan oleh hakim yang mempunyai kelayakan dalam bidang Undang-undang Islam. Jika terdapat kes yang bertindan dalam kedua-duanya, undang-undang Sivil mahupun Islam, maka hakim yang berkelayakan dalam undang-undang Sivil dan Islam hendaklah membicarakannya bersama. Antara penulisan lain adalah oleh Zainal Amin Ayub dan Zuryati Mohamed Yusoff (2007: xcix-cxxii) yang membandingkan mengenai perkara peribadi atau kebebasan diri dalam Undang-undang Syariah dan Sivil. Manakala penulisan Wan Mahyuddin (2010: 83-105) pula membincangkan tentang konflik bidangkuasa Mahkamah Syariah dalam kes penukaran agama. Antara kes yang diulas ringkas oleh penulis ialah Eswari Visuvalingam lwn Kerajaan Malaysia, Pedley lwn. Majlis Agama Islam Pulau Pinang, Ng Siew Pian lwn. Abdul Wahid Abu Hassan \& Anor, Tey Siew Choo lwn. Teo Eng Hua, Kamariah Ali \& Yang Lain dan Tan Sung Mooi lwn. Too Miew Kim.

Penulisan khusus mengenai pindaan Perkara 121 (1A) Perlembagaan Persekutuan yang menghalang Mahkamah Sivil campur tangan dalam bidangkuasa Mahkamah Syariah pernah dibincangkan oleh Ahmad Ibrahim (1990:129-137) yang menyatakan bahawa kesan terbesar pindaan tersebut adalah untuk mengelakkan pertindihan bidangkuasa antara Mahkamah Syariah dan Mahkamah Sivil. Manakala, penulisan Zulazhar Tahir (2003: 149-160) dan Sharifah Suhanah (2005: 311-322) mengulas secara ringkas beberapa kes yang menghadapi pertikaian seperti Shahamin Faizul Kung, Faridah Dato Talib, Sukma Darmawan Sasmitaat Madja, Isa Abdul Rahman, Ng Wan Chan, Dalip Kaur, Faridah Dato Talib, Lim Chan Seng, Soon Singh a/l Bikar Singh. Melihat perkembangan Mahkamah Syariah kini, telah berlaku beberapa perubahan dan penambahbaikan walaupun masih terdapat beberapa perkara yang menjadi isu berbangkit. 
Menurut Ahmad Hidayat Buang (2005: 1-17) institusi Mahkamah Syariah sedang mengalami suatu proses transformasi daripada institusi tradisional kepada institusi kehakiman Islam yang moden dan dinamik. Penulisannya turut membincangkan beberapa pencapaian yang telah dicapai oleh Mahkamah Syariah. Antaranya ialah pindaan Perkara 121 (1A) pada tahun 1988 yang membebaskan Mahkamah Syariah dari campur tangan Mahkamah sivil, pemisahan pentadbiran Mahkamah Syariah daripada Majlis Agama Islam, perundangan yang lebih jelas dan komprehensif melalui pindaan enakmen dan akta-akta tertentu, mempunyai skim perkhidmatan dan latihan kakitangan yang lebih baik dengan penubuhan Jabatan Kehakiman Syariah. Selain itu, Mahkamah Syariah kini mempunyai kemudahan dan infrastruktur yang baru serta dapat memberikan keselesaan kepada pegawai untuk bertugas. Malah, mahkamah tersebut telah memperkenalkan sistem online iaitu e-Syariah untuk kemudahan orang awam mengakses apa-apa maklumat yang berkaitan. Perkara ini juga terlebih dahulu pernah dibincangkan oleh Mahmud Saedon Awang Othman (1984: 30) yang mencadangkan untuk mempertingkatkan Mahkamah Syariah dari segi bidangkuasa, taraf, pentadbiran dan pengurusan, pindaan kepada peruntukan Perlembagaan dan akta-akta yang menyekat pelaksanaan Undang-undang Islam perlu dilakukan. Seterusnya, penyeragaman dan pelarasan pentadbiran Mahkamah Syariah di seluruh negara, perlu dibuat.

\section{KESALAHAN JENAYAH SYARIAH DALAM KERANGKA PERUNDANGAN DI MALAYSIA}

Undang-undang Jenayah Syariah berada di bawah bidangkuasa negeri dan perkara ini telah termaktub dalam perkara 74 dan Jadual Kesembilan, Senarai II, Senarai Negeri Perlembagaan Persekutuan. Undang-undang Jenayah Syariah tersenarai dalam undang-undang diri antara individu dengan Allah SWT. Ini kerana, setiap kesalahan jenayah syariah itu adalah perkara yang turut dilarang oleh agama. Namun, ada juga individu yang mempersoalkannya kerana mendakwa sebahagiannya adalah merupakan hak kebebasan asasi (fundamental liberties) yang telah diperuntukkan dalam Perlembagaan Persekutuan. Banyak penulisan dan kajian berkenaan dengan Undang-undang Syariah di Malaysia dari sudut perkembangan, pelaksanaan, saranan dan penambahbaikan yang perlu dilaksanakan, yang telah ditulis oleh para sarjana. Konsep umum dalam Undang-undang Jenayah Syariah seperti matlamat asal Syariah, matlamat dalam jenayah Syariah itu sendiri, kelebihannya berbanding dengan pandangan barat dan konsep hukuman dalam Islam pernah dibincangkan oleh Daud Muhammad (2015: 7-31) dalam penulisannya. Penulis juga ada menjelaskan berkenaan kesalahan jenayah syariah menurut Akta Jenayah Syariah (Bidangkuasa Jenayah) 1965 (pindaan) 1984 (AJS84) 
serta perbandingannya dengan kesalahan jenayah yang terdapat dalam Islam dan menyentuh ringkas mengenai Undang-undang Keterangan Syariah.

Siti Zubaidah Ismail (2005: 93-101), dalam artikelnya secara ringkas menyentuh mengenai pelaksanaan Undang-undang Jenayah Syariah di Malaysia dengan menyorot perkembangan awal di Tanah Melayu. Selain itu, turut dibincangkan mengenai bidangkuasa dan kesalahan jenayah syariah dalam Islam serta hukuman yang diperuntukkan. Ini boleh dibandingkan dengan penulisan Abdul Halim el-Muhammady (2005: 373-419) dalam penulisannya yang membincangkan mengenai perkembangan pelaksanaan Undang-undang Jenayah Syariah dari zaman penjajahan hingga selepas merdeka. Selain itu, turut disenaraikan jenis-jenis kesalahan jenayah syariah yang terkandung dalam enakmen dan analisis kanun jenayah syariah negeri Kelantan. Walaupun beliau tidak menyentuh mengenai permasalahan dalam Undang-Undang Jenayah Syariah, tetapi penulis ada memberikan beberapa saranan penambahbaikan seperti membuat perubahan Undang-undang Islam yang bersesuaian dengan ajaran Islam sebenar, perluasan skop Undangundang Jenayah Islam, memperkasakan bentuk hukuman penjara dan sebat serta mempertahankan peruntukan 121 (1A).

Walaupun kesalahan jenayah syariah telah dikanunkan menjadi satu peruntukan undang-undang, namun terdapat beberapa isu dan masalah yang dihadapi oleh peruntukan tersebut. Antaranya ialah kegagalan dalam melaksanakan tindakan penguatkuasaan kesalahan jenayah syariah, kedudukan mengenai kesalahan murtad, keberkesanan hukuman yang diperuntukkan (Siti Zubaidah Ismail, 2012: 109-125). Penulis turut mencadangkan beberapa penambahbaikan seperti meminda Akta Jenayah Syariah 1984, menyelaraskan Enakmen Kesalahan Jenayah Syariah Negeri, menambahkan kesalahan yang lebih spesifik berkaitan ajaran salah, melaksanakan hukuman sebat di semua negeri dan menerima pakai Arahan Tetap Pengarah JAWI 2007 dengan segera.

Musa Awang (2015: 68-82) pula dalam penulisannya menyatakan antara masalah yang dihadapi berkaitan dengan isu bidangkuasa Mahkamah Syariah ialah kerana bidangkuasa mahkamah adalah terhad kepada orang Islam sahaja. Ini menimbulkan konflik sekiranya kesalahan jenayah syariah yang dilakukan antara salah seorang pasangan itu bukan beragama Islam seperti jenayah khalwat dan zina. Selain itu, masalah ketidakseragaman undangundang antara negeri-negeri termasuk jenis kesalahan jenayah syariah dan bentuk hukuman yang diperuntukkan. Seterusnya ialah masalah berkaitan dengan penguatkuasaan dan pendakwaan. Contohnya kekurangan Pegawai Penguatkuasa Agama (PPA) wanita, tahap pendidikan para pegawai, kekurangan latihan bagi PPA untuk prosedur penyamaran, kekurangan 
sistem komunikasi untuk menjalankan operasi dan masalah kewangan yang akan memberikan kesan kepada pertambahan jawatan serta infrastruktur yang diperlukan. Oleh itu, beberapa cadangan atau saranan diperlukan bagi mengatasi permasalahan tersebut. Kajian mengenai cadangan atau penambahbaikan dalam Undang-Undang Jenayah Syariah pula telah dikupas oleh Jasri Jamal (2012: 20-24) yang berpendapat bahawa bidangkuasa jenayah hendaklah ditambah kepada hukuman yang lebih tinggi serta melakukan transformasi di bahagian penguatkuasaan sama ada di agensi penguatkuasaan sendiri atau di bahagian undang-undang substantif yang berkaitan dengannya. Penulis turut menyatakan kesan jika perubahan dilakukan profesion guaman syarie mungkin dapat dijalankan dengan lebih berkesan dalam kes jenayah syariah tanpa mengambil jalan mudah dengan meminta anakguam mengaku salah memandangkan hukuman yang bakal dikenakan adalah ringan dan dapat meningkatkan profesion Pegawai Penguatkuasa Agama dan Pendakwa Syarie untuk membuktikan kes-kes yang sukar seperti yang melibatkan akidah.

Jasri Jamal dan Hasnizam Hashim (2014: 92-100) pula mencadangkan antara sebab atau faktor mengapa bentuk hukuman bagi kes jenayah syariah perlu dikaji semula adalah kerana keterbatasan pemilihan bentuk hukuman oleh Hakim Syarie, kejumudan tentang pemahaman konsep ta 'zì r, hukuman yang sedia ada tidak dapat diketahui sejauhmana keberkesanannya dan ketidakseragaman hukuman bagi kesalahan yang sama dalam Akta atau Enakmen Jenayah Syariah Negeri-Negeri seperti menghina agama, mengajar agama tanpa tauliah, tidak membayar zakat fitrah, penyalahgunaan tanda halal dan minuman yang memabukkan. Siti Zubaidah Ismail (2014: 17-24) pula mencadangkan mewujudkan dewan bicara khas kes jenayah, melantik hakim khas jenayah di Mahkamah Rendah dan Mahkamah Tinggi, mewujudkan penjara khas syariah, menambah bidangkuasa hukuman sebat hingga 100 kali sebatan dan meminda kadar hukuman bagi tiga kesalahan hudud. Apabila membincangkan mengenai Undang-undang Jenayah Syariah di Malaysia, persoalan hudud menjadi salah satu perbahasan hangat dalam kalangan sarjana dan ahli perundangan. Antaranya ialah kajian Mohammad Hashim Kamali (1998: 203-234) yang mengkritik peruntukan Rang Undang-Undang Hudud di Kelantan. Penulis membincangkan tentang tiga permasalahan yang terkandung dalam rang tersebut iaitu kekurangan bidangkuasa yang membawa kepada percanggahan dengan Perlembagaan Persekutuan, kedua ialah masalah berkaitan dengan masyarakat dan politik di Malaysia dan ketiga ialah permasalahan dalam memahami maksud hudud sebenar. Penulis turut menganalisis tentang konsep hudud yang terkandung dalam al-Quran dan fiqh.

Sayed Sikandar Shah Haneef (2010: 131-144) pula membincangkan tentang kemungkinan dan ketidakmungkinan untuk melaksanakan undang- 
undang hudud dalam kerangka undang-undang sekarang. Penulis juga menyatakan dua pendekatan dalam kemungkinan untuk melaksanakannya iaitu menggubal semula kanun keseksaan dan mengislamisasikannya. Manakala, ketidakmungkinan untuk melaksanakannya pula adalah kerana Negara Malaysia menurut definisi dalam Perlembagaan Persekutuan bukanlah negara Islam sepenuhnya dan struktur undang-undang semasa yang membuatkannya mustahil untuk melaksanakan hudud kerana ketiadaan kesepakatan antara ahli Parlimen untuk meminda Perlembagaan. Selain itu, penulis turut menyentuh secara ringkas mengenai perselisihan pendapat berkenaan bilangan kesalahan hudud. Penulis juga berpendapat bahawa semua undang-undang perlu diselaraskan dengan prinsip $t a ' z \bar{l} r$ walaupun menyentuh jenayah serius seperti hudud. Isu hudud yang dikupas oleh Siti Zubaidah Ismail (2014: 193-212) dalam kajiannya pula adalah berkaitan kedudukan hudud dan kesalahan jenayah syariah secara umum dan mencadangkan dimensi baru bagaimana cara memandang dan memahami isu hudud dan bukannya dibayangi oleh rasa takut berkaitan hudud. Penulis juga menyatakan bahawa secara hakikatnya bukan Perlembagaan yang menghalang pelaksanaan hudud itu tetapi AJS84. Justeru hukuman dalam Akta ini yang seharusnya dipinda hingga keseratus sebatan.

Selain itu, terdapat juga penulisan mengenai kedudukan Undang-undang Jenayah Syariah di bawah Perlembagaan Persekutuan. Antaranya ialah penulisan Mohamed Azam Mohamed Adil (2003: 23-38) Shamrahayu A. Aziz (2007: 101-120) dan Farid Sufian Shuaib (2011: i-xvi) dan (2015: 33-51). Kajian tersebut membincangkan hubungkait antara undang-undang jenayah syariah dengan perlembagaan di Malaysia, isu murtad, kebebasan asasi dalam Perlembagaan Persekutuan yang diulas ringkas iaitu Perkara 5 (Kebebasan Diri), 8 (Kesamarataan), 9 (Kebebasan Bergerak) dan 11 (Kebebasan Beragama) serta kes-kes syariah yang telah dilaporkan, antaranya, kes Lina Joy lwn. Majlis Agama Islam Wilayah Persekutuan \& Lain-lain, Muhamad Juzaili Mohd Khamis \& Ors. Iwn. Kerajaan Negeri Sembilan \& Lain-lain, Sulaiman Takrib lwn. Kerajaan Negeri Terengganu, Fathul Bari Mat Jahya lwn. Majlis Agama Islam Negeri Sembilan dan Berjaya Books Sdn Bhd \& Lain-lain lwn. Jabatan Agama Islam Wilayah Persekutuan \& Ors.

\section{KESIMPULAN}

Melihat kepada sorotan literatur yang diulas, kajian atau penulisan mengenai semakan kehakiman perundangan sivil sememangnya telah banyak dikaji namun kajian khusus mengenai semakan kehakiman Mahkamah Sivil terhadap undang-undang Syariah dan kesalahan jenayah Syariah di Malaysia, masih 
kurang dan tidak banyak diterokai oleh para pengkaji. Sedangkan kes-kes semakan kehakiman sama ada mal (sivil) atau jenayah Syariah semakin banyak dipohon di Mahkamah Sivil. Oleh itu, satu kajian terperinci dan mendalam perlu diusahakan untuk mengkaji berkenaan isu ini kerana ianya dillihat akan memberikan implikasi terhadap beberapa aspek seperti kedudukan Islam dan Undang-undang Islam, kebebasan asasi, peruntukan Undang-undang Jenayah Syariah, institusi agama Islam dan fatwa, Mahkamah Syariah dan masyarakat khususnya umat Islam.

\section{RUJUKAN}

Abd. Jalil Borham (1998). Penubuhan Mahkamah Syariah dan Bidangkuasanya di Malaysia. ed.Ahmad Hidayat Buang. Undang-Undang Islam di Mahkamah Syariah di Malaysia. Kuala Lumpur: Jabatan Syariah Undang-Undang, Akademi Pengajian Islam, Universiti Malaya.

Abdul Halim el-Muhammady (2005). "Undang-Undang Jenayah Syariah dan Pelaksanaannya di Malaysia," Malaysia Sebagai Sebuah Negara Islam. Kuala Lumpur: Institut Kefahaman Islam Malaysia.

Abdul Hamid Mohamad (2002). Civil and Syariah Courts in Malaysia: Conflict of Jurisdiction. Malayan Law Journal, vol. 1.

Abdul Samat Musa (1997). "Konsep Ketertinggian Perlembagaan: Satu Pengamatan Umum dari Perspektif Perlembagaan Islam dan Perlembagaan Malaysia," Isu Syariah dan Undang-undang, ed. Jafril Khalil. Bangi: Jabatan Syariah, Fakulti Pengajian Islam, UKM.

Abdul Samat Musa \& Zuliza Kusrin (2006). Undang-undang Perlembagaan Pentadbiran. Bangi: Pusat Kembangan Pendidikan UKM.

Abdulfatai Sombo \& Hunud Abia Kadouf (2014). "A Judicial Review of Political Questions Under Islamic Law," Intellectual Discourse, vol. 22, no. 1 .

Ahmad Hidayat Buang (2005). "Mahkamah Syariah di Malaysia Pencapaian dan Cabaran Alaf Baru," Mahkamah Syariah di Malaysia Pencapaian dan Cabaran, ed. Ahmad Hidayat Buang. Kuala Lumpur: Penerbit Universiti Malaya.

Ahmad Ibrahim (1997). "Kedudukan Undang-undang Islam di Malaysia," Jurnal Hukum, vol. 11, No. 2 (Disember).

Ahmad Ibrahim (1990). "Pindaan kepada Perkara 121 Perlembagaan Persekutuan dan Kesannya kepada Pentadbiran Undang-Undang Islam," Jurnal Hukum, vol. 7, No. 2. 
Ahmad Ibrahim (1993). "The Future of the Shariah and Shariah Courts in Malaysia," Jurnal Undang-Undang, vol. 20 (Jun-Disember).

Ahmad Ibrahim (1995). “Undang-undang Islam di Mahkamah Sivil," Jurnal Hukum, vol. 10, no. 1 (November).

Ahmad Ibrahim (1995). "Sistem Kehakiman Islam di Malaysia Masa Kini," Jurnal Hukum, vol. 10, no. 1 (November).

Ahmad Masum (2010). "The Doctrine of Judicial Review: Cornerstone of Good Governance in Malaysia," Malayan Law Journal, vol. 6.

Choo Chin Thye (2002). "The Role of Article 8 of the Federal Constitution in the Judicial Review of Public Law in Malaysia," Malayan Law Journal, vol. 3.

Daud Muhammad (2015). "Falsafah Pentadbiran Keadilan Jenayah Syariah: Satu Penghayatan Semula," Jurnal Kanun, vol. 27 (Januari).

David S. Powers (1992). “On Judicial Review in Islam," Journal of the Law and Society Association, vol. 26, no. 2.

Dina Imam Supaat (2000). "Extra Judicial Review of Administrative Action and Decisions in Malaysia," (Disertasi Sarjana Undang-undang, Fakulti Undang-Undang, Universiti Kebangsaan Malaysia, Bangi).

Farid Sufian Shuaib (2011). “Administration of Shariah Criminal Justice under The Malaysian Constitutional Framework: Issues and Suggestions," The Malayan Law Journal, vol. 6.

Farid Sufian Shuaib (2015). "Isu Perlembagaan dan Hak Asasi Manusia dalam Pentadbiran Keadilan Jenayah Syariah," Jurnal Undang-undang Malaysia, vol. 27 (Januari).

Farid Sufian Shuaib (2008). Powers and Jurisdiction of Syariah Courts in Malaysia. Petaling Jaya: Lexis Nexis Malaysia Sdn. Bhd.

Gan Ching Chuan (1991). “Administrative Law: An Update," Malaysian Current Law Journal, vol. 3.

Ghazali Abdul Rahman (1997). "Kedudukan Mahkamah Syariah di Bawah Perlembagaan," Jurnal Hukum, vol. 11, no. 2 (Disember).

Ghazali Abdul Rahman (2007). "Kuasa Kehakiman Islam di Malaysia," Malaysia sebagai Sebuah Negara Islam. Kuala Lumpur: Institut Kefahaman Islam Malaysia.

Malayan Law Journal, Halsbury Law of Malaysia. Jilid. ke 9. 2001. Kuala Lumpur: Malayan Law Journal Sdn. Bhd.

Hari Chand (1998). "Malaysian Administrative Law: Has It Come of Age," Malaysian Journal Law of Society, vol. 2. 
Ibnor Azli Ibrahim \& Yazid Ahmad (2005). "Pembentukan Mahkamah Syariah di Malaysia dan Bidangkuasanya," Isu Syariah dan Undang-Undang, ed. Mohamad Zaini Yahya \& Abdul Basir Mohamad. Bangi: Jabatan Syariah, Fakulti Pengajian Islam, Universiti Kebangsaan Malaysia.

Jasri Jamal \& Hasnizam Hashim (2014). “Transformasi Mahkamah Syariah di Malaysia: Keperluan Kajian Semula Terhadap Bentuk Hukuman bagi Kes-Kes Jenayah Syariah," Ulum Islamiyyah Journal, vol. 12 (Jun).

Jasri Jamal (2012). "Pertambahan Bidangkuasa Jenayah Syariah: Impaknya Terhadap Institusi Kehakiman Syariah di Malaysia," Shariah Law Reports, vol. 1.

Jayanthi Naidu (2004). "Reviewing Judicial Review: Constitutional and Institutional Competence," (Disertasi Sarjana Undang-Undang, Fakulti Undang-Undang, Universiti Malaya, Kuala Lumpur).

Khairil Azmin Mokhtar \& Siti Aliza Alias (2013). "The Doctrine of Seperation Powers: Judicial Review as a Check and Balance Tool," Constitutional Law and Human Rights in Malaysia, ed. Khairil Azmin Mokhtar. Petaling Jaya: Sweet \& Maxwell Asia.

Mahmud Saedon A. Othman (1990). "Bidangkuasa Mahkamah Syariah," Jurnal Hukum, vol. 7, no. 1 (Mac).

Mahmud Saedon A. Othman (1984). "Ke Arah mempertingkatkan Mahkamah Syariah," Jurnal Hukum, vol. 5, no. 1 (September).

Mohamad Hashim Kamali (1998). "Punishment in Islamic Law: A Critique of the Hudud Bill of Kelantan Malaysia," Arab Law Quarterly, vol. 13, no. 3 .

Mohamed Azam Mohamed Adil (2000). "Bidangkuasa dan Kedudukan Mahkamah Syariah di Malaysia Pasca Alaf 20: Ke Arah Mana," Jurnal Syariah, vol. 8, no. 2.

Mohamed Azam Mohamed Adil (2003). "Hak Tukar Agama dalam Perlembagaan Malaysia: Konflik antara Kebebasan Beragama dan Hukum Islam,” Jurnal Syariah, vol. 11, no. 1.

Musa Awang (2015). "Di manakah Kita dalam Pemantapan Pentadbiran Keadilan Jenayah Syariah," Jurnal Kanun, vol. 27, no. 1 (Januari).

Narizan Abdul Rahman (2005). "Bidangkuasa Mahkamah dan Konflik Perundangan," Mahkamah Syariah di Malaysia Pencapaian dan Cabaran, ed. Ahmad Hidayat Buang. Kuala Lumpur: Penerbit Universiti Malaya. 
Narizan Abdul Rahman (1999). "Isu-isu Semasa Bidangkuasa Mahkamah Syariah: Satu Sorotan dalam Kes Jenayah Syariah Liwat," Jurnal Syariah, vol. 7, no. 2.

Nayel Musa Shanker Al-Omran et al. (2015). "Historical and Political Background of Judicial Review in the Islamic Legal System," American Research Journal of History and Culture, vol. 1, no. 1.

Noor Aziah Mohd Awal (2003). Pengenalan kepada Sistem Perundangan di Malaysia. Selangor: International Law Book Service.

Ramizah Wan Muhammad (2011). "The Administration of Syariah Courts in Malaysia 1957-2009," Journal of Islamic Law and Culture, vol. 13 (July-October).

Sayed Sikandar Shah Haneef (2010). "Discourse on Hudud in Malaysia: Addressing the Missing Dimension," Journal of Islamic Law and Culture, vol. 12, no. 2.

Shaikh Salim Shaikh Salleh (2001). Sistem Undang-Undang di Malaysia. Bangi: Pusat Perkembangan Pendidikan UKM.

Shamrahayu A. Aziz (2007). "Islamic Criminal Law in The Malaysian Federal Structure: A Constitutional Perspective," IIUM Law Journal, vol. 15, no. 1.

Sharifah Suhanah S. Ahmad (2005). "Empowering the Shariah Court in Malaysia- Article 121 (1A) Re-Visited," Jurnal Undang-Undang, vol. 9, no. 1 (Januari-Jun).

Siti Rohida Asrani \& Zuliza Kusrin (2016). "Konsep Semak dan Imbang Menurut Islam dan Aplikasinya dalam Sistem Kehakiman Islam," Jurnal Syariah, vol. 24, no. 1.

Siti Zubaidah Ismail (2014). "Hudud dan Undang-Undang Jenayah Syariah dalam Kerangka Perlembagaan dan Sistem Perundangan Dualisme: Komitmen Pelaksanaan ke Arah Membendung Jenayah di Malaysia," Jurnal Syariah, vol. 22, no. 2 (Mei-Ogos).

Siti Zubaidah Ismail (2012). "Kajian Semula Terhadap Undang-Undang Jenayah Syariah," Korpus Undang-Undang Islam di Malaysia Semakan dan Cabaran, ed. Siti Shamsiah Md. Supi. Kuala Lumpur: Institut Kefahaman Islam Malaysia.

Siti Zubaidah Ismail (2014). "Pemerkasaan Mahkamah Syariah dalam Pengurusan Kes Jenayah Syariah," Jurnal Hukum, vol. 38, no. 1 (Februari). 
Siti Zubaidah Ismail (2005). "Undang-undang Jenayah Islam dan Pelaksanaan Jenayah Syariah di Malaysia," Mahkamah Syariah di Malaysia Pencapaian dan Cabaran, ed. Ahmad Hidayat Buang. Kuala Lumpur: Penerbit Universiti Malaya.

Suzana Muhamad Said (2001). "Semakan Kehakiman di Malaysia: Masalah, Halangan dan Cabaran," (Disertasi Sarjana Undang-Undang, Fakulti Undang-Undang, Universiti Kebangsaan Malaysia, Bangi).

Wan Azlan Ahmad \& Nik Ahmad Kamal Nik Mahmod (2006). Administrative Law in Malaysia. Petaling Jaya: Sweet \& Maxwell Asia.

Wan Azlan \& Mohsim Hingun (1995). An Introduction to Adminstrative Law. Singapura: FT Law \& Tax Asia Pasific.

Zainal Amin Ayub \& Zuryati Mohamed Yusoff (2007). "Leave Me Alone: Syariah and Civil Law," Malayan Law Journal, vol. 6.

Wan Mahyuddin Wan Muhammad (2010). "Shariah Courts: Conflicting Jurisdiction in Conversion Cases," Shariah Law Reports, vol. 4.

Zaini Nasohah (2004). Pentadbiran Undang-undang Islam di Malaysia Sebelum dan Menjelang Merdeka. Kuala Lumpur: Utusan Publications \& Distributors.

Zulazhar Tahir (2003). "Mahkamah Syariah Selepas 16 Tahun Kemasukan Artikel 121 (1A) Perlembagaan Persekutuan," Jurnal Undang-Undang, vol. 30 , no. $1 \& 2$. 